\title{
DIVERSITY AND POPULATION OF AVIFAUNA OF TWO URBAN SITES IN DHAKA, BANGLADESH
}

\author{
Noor Jahan Sarkar, Dilruba Sultana, M. Firoj Jaman* and M. Khalilur Rahman \\ Department of Zoology, University of Dhaka, Dhaka 1000, Bangladesh \\ *Department of Ecology and Social Behavior \\ Primate Research Institute, Kyoto University \\ 41-2 Kanrin, Inuyama, Aichi, 484-8506, Japan \\ Email:mfjaman@yahoo.com
}

\begin{abstract}
A comparative study on diversity and population status of avifauna in Uttara urban area of Dhaka city with their breeding records was done in 12-months period from August 2004 to July 2005. A total of 27 species of birds were recorded from two urban sites (Sectors 7 and 9). Species diversity was significantly more in Sector 7 than that recorded in Sector 9. Regarding the relative abundance, the highest number of species of birds $(44 \%)$ was very common in Sector 7 . In contrast, the number of rare species $(33.33 \%)$ was significantly high in Sector 9. Corvus splendens, C. macrorynchus, Passer domesticus and Sturnus contra were most dominant species in both study sites. On the taxonomic view point of avifauna, $14(51.85 \%)$ species were passerines and $13(48.15 \%)$ were non passerines. Six species of breeding birds were recorded, and all of them constructed nests in Sector 7 and only 2 species constructed nests in Sector 9. These data suggest that Sector 7 is more suitable habitat than the other. Preferences for nesting sites were significantly higher on the indigenous trees in both study sites, meaning that vegetation is important factor affecting the abundance of urban avifauna.
\end{abstract}

Key words: Avifauna, diversity, population ecology, urban area, conservation.

\section{INTRODUCTION}

Diversity of avifauna is one of the most important ecological indicators to evaluate the quality of habitats. Now-a-days, avifaunal diversity has been decreasing due to the destruction of natural habitats and human disturbances. Random destruction of natural habitats by cutting nesting trees and foraging plants for commercial use of woods and lands are the main factor responsible for narrow down in avian foraging habitat and their nesting sites. Thus, many species of birds may be forced to inhabit in the urban areas and constrain them to breed there. Birds are essential animal group of an ecosystem and maintain a trophic level. Therefore, detail study on avifauna and their ecology is important to protect them.

Studies on behavior and breeding ecology of birds are well done (Baker 1920-30, Wallace 1963, Ali and Ripley 1983b, Lodge 1991, Kotpal 1992, Ali 1996, Khan 1996, Sruti 2008). There are reports on avifauna in different regions of Bangladesh. These reports include: Islam (1969) in Rangpur district, Husain $(1969$, 1975) in Chittagong Hill Tracts and Pablakhali wildlife sanctuary, Banerjee (1978) and Das (1975) in Curzan hall area and Ramna Park, Khan (1982) 
and Sarker et al. (2001) in St. Martin Island, Sarker and Sarker (1986) in Sundarban, Haque and Rahman (1993) in Raman and Suhrawardy parks and Akhter (1997) in Boldha garden. Sarkar (1984) studied seabirds of the Bay of Bengal of Bangladesh coast and their conservation. Jaman et al. (1997) studied breeding biology of the black drongo, Jaman and Sahreen (2004) on ecology and breeding biology of chestnut-tailed starling and Jaman et al. (2004) studied ecology, conservation problems and status of avifauna of Noakhali Charbata Coastal area. Diversity of avifauna in Bagkhali range was studied by Sarker et al. (2000, 2001).

No research on avifauna was carried out in the urban area of Uttara Model Town and its adjacent areas. We selected this study site as it was natural habitat with many jungles and agricultural lands where many species of birds and other wild animals lived before urbanization. Still a viable population of some bird species inhabits this urban and /or semi-urban habitats. Our study is an attempt to prepare a baseline data on avifauna with their relative abundance and breeding records of resident birds in two different ecological sites in the urban area of Uttara Model Town of Dhaka City Corporation, Bangladesh.

\section{MATERIALS AND METHODS}

\section{Study sites}

The study was conducted from August 2004 to July 2005 in two study sites; Sector-7 and Sector-9 of Uttara Model Town under Dhaka City corporation, Bangladesh. The avifauna and their breeding records were studied in both study sites and compared.

\section{Data collection}

The study area was visited 4 days in a month. A total of 48 days were spent counting birds, sampling plants and collecting other ecological data. Sampling was started at 7:00 and continued until 17:00. Observation was made equally across the season and at different time of the day. Birds were counted by transect line, point counting and look and see methods. We used field binocular to observe and identify bird species. We used some taxonomic books (Baker 1920-30, Ali and Ripley 1983a,b Lodge 1991, Kotpal 1992 and Ali 1996) to identify birds upto species level. Observations were made by standing and sitting from a hiding place. Photographs were taken where ever necessary to identify birds accurately to the generic and species level. In addition, breeding birds were recorded and vegetation sampling was done during the study period. In case of point counting method, distance between two points was $50 \mathrm{~m}$ and observation was only performed forwardly that is only towards the direction of our movement. Duration at each point for counting sign, recording calls and investigating nest of birds was $5 \mathrm{~min}$. Each method was used in the successive observation days. In case of line transect method, observation was performed through a straight line (50 $\mathrm{m}$ breadth and $500 \mathrm{~m}$ length). Random-direct counting was performed for several times. The adopted methods were performed according to the habitat types in order to cover the entire study area for counting birds. Topography of the two study sites was not similar, therefore, we applied different methods to count the population density of birds and identify them up to the generic and species level.

\section{Data analysis}

All records were kept in the tabulated form in the excel data sheets. The average number of individual species of bird was calculated for each area. Systematic list and status of the birds was constructed on the basis of each taxon and calculated their relative abundance according to Sarker and Sarker (1988), IUCN (2000) and Hossain et al. (2004). Birds are very common (VC) if the species was observed during almost all 
the visits by more than 7 individuals. Grouped as fairly common (FC) if the species was observed during $30-70 \%$ of the visits by $3-6$ individuals. Species those were observed $<3$ individuals, were categorized as rare $(\mathrm{Ra})$ species. Chi-square test was done to compare the proportion of species diversity and selection ratio of nesting sites between two study sites. T-test was employed to compare the annual mean population of birds counted from the two sites. Fisher's exact test was done to elucidate significant variation of relative abundance of the species. Statistical analysis was done using SPSS (13 version). Significant level was set at $\mathrm{p}<0.05$.

\section{STUDY AREA}

The two study areas, Sectors 7 and 9 are situated at Uttara in Dhaka city. Dhaka city $\left(23^{\circ} 40^{\prime}\right.$ W longitudes and $90^{\circ} 80^{\prime} \mathrm{E}$, about 25 feet above the sea level). The climate is tropical. Maximum temperature was recorded $33.4^{\circ} \mathrm{C}$ in April and minimum $14.1^{0} \mathrm{C}$ in January (Fig. 1). The maximum rainfall was $542 \mathrm{~mm}$ in July and minimum was $03 \mathrm{~mm}$ in February. No rainfall was recorded in November and December (Fig. 1). Humidity varied from 36 to $99 \%$. The climate of Bangladesh has been divided into three seasons: winter (November to February), summer (March to June) and Monsoon (July to October).

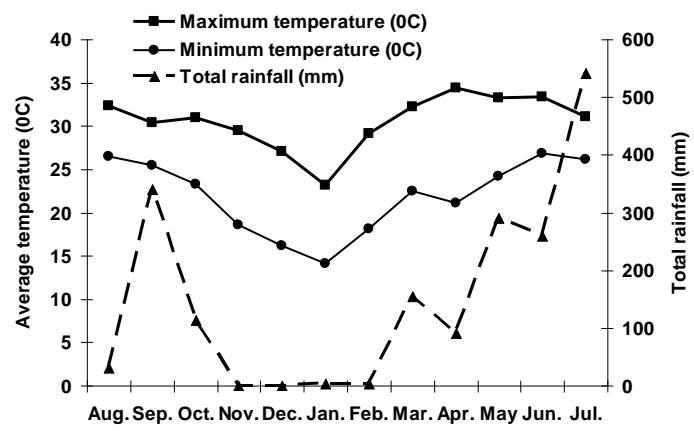

Fig. 1. Monthly mean temperature $\left({ }^{0} \mathrm{C}\right)$ and rainfall $(\mathrm{mm})$ in Dhaka city.
The Sector 7 study site is in the heart of Uttara Model town. There is a park with some trees in this study site. A lake passes away in the western side of this sector. Residential houses and public places are scattered here and there. The landmass of the area is flat and plain. Vegetation is classified into natural and planted trees as well as shrubs and vegetable gardens. Fifty three species of trees and shrubs were identified during the study period. The mentionable species are coconut (Cocos nucifera), fig (Ficus hispida), banyan ( $F$. benghalensis), peacock flower (Delonix regia), guava (Psidium guyava), black berry (Syzygium cumini), Eucalyptus citridora and dalia (Dahlia hybrida).

The Sector 9 study site is still urbanizing with the construction of various infrastructures and residential houses. In the north side, the boundary of Uttara model town and east side bound by Dhaka-Mymensingh highway. A lake touches on the west-north corner of this sector. There is no park and gardens developed here as public properties. In this study site landmass is also flat and plain. Forty species of trees and shrubs were identified. The vegetation types and species are similar as identified in Sector 7 but comparatively less abundant.

\section{RESULTS}

\section{Species composition}

A total of 27 species of birds belonging to 14 families and 8 orders were recorded from the two study sites (Sectors 7 and 9). Among these, 14 $(51.85 \%)$ were passerines and $13(48.15 \%)$ non passerine birds. The passerine birds belonged to 6 families under only one order and non-passerine birds belonged to 8 families under 7 orders.

\section{Species diversity and relative abundance between study sites}

Species diversity in Sector 7 was (25 species) significantly higher than that of Sector 9 (18 
species $)\left(\chi^{2}=4.0, \mathrm{p}<0.05, \mathrm{df}=1\right)$. Among the avifauna, 24 species $(88.89 \%)$ were resident and 3 $(11.11 \%)$ were migratory. In Sector 7 , species diversity was more (25 species of birds) in June and was less (18 species) in December. In contrast, species diversity was more (18 species of birds) in July and less (13 species) in December in Sector 9. Comparison of monthly variation of mean species diversity between two study sites is illustrated in the Fig 2. Monthly mean variation of species occurrence in Sector 7 was more $(21.92 \pm 2.15)$ than that found in Sector $9(14.42 \pm 2.43)$ and mean difference was statistically highly significant $(\mathrm{t}=8.01, \mathrm{p}<0.001, \mathrm{df}=22)$.

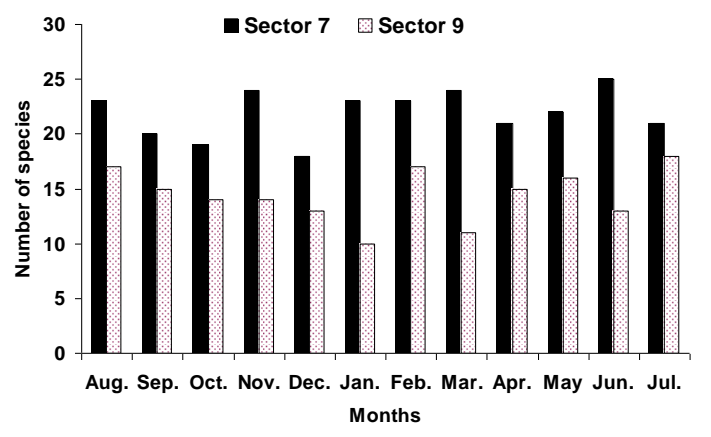

Fig. 2. Comparison of monthly variation of mean species diversity of birds between two study sites.

In Sector 7, a total of 25 species of birds belonging to 14 families under 8 orders were recorded. Among these, 14 species (56\%) were passerines and $11(44 \%)$ were non passerine birds.
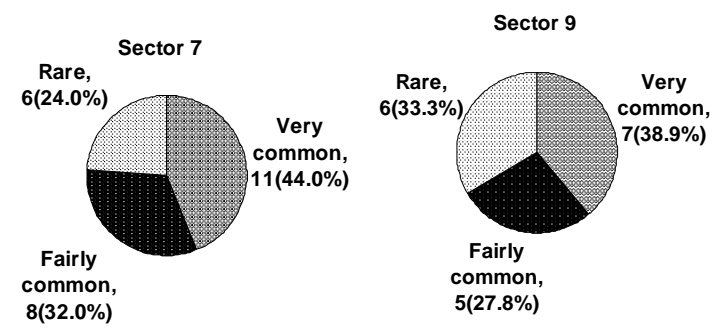

Fig. 3. Comparison of relative abundance of bird species between Sector 7 and Sector 9 study sites.
Regarding the resident status, 22 (88\%) were resident and $3(12 \%)$ migrants. Relative abundance of bird species in Sectors 7 and 9 are shown in Fig. 3 . The highest density was found for house crow (40.16 individuals $/ \mathrm{km}^{2}$ ) followed by house sparrow (14.28 individuals $/ \mathrm{km}^{2}$ ) and large-billed crow (10.45 individuals $/ \mathrm{km}^{2}$ ). Regarding the relative abundance of species, the highest number of species (44\%) was very common (Fig. 3).

In contrast, in Sector 9, a total of 18 species of birds belonging to 12 families under 8 orders were recorded. The proportion of passerine birds was $50 \%$ of the total avifauna and rest $50 \%$ were nonpasserines. All bird species in this study site were resident. The highest density was found for house crow (31.08 individuals $/ \mathrm{km}^{2}$ ) followed by house sparrow (11.27 individuals $/ \mathrm{km}^{2}$ ) and large-billed crow (7.54 individual $/ \mathrm{km}^{2}$ ). Regarding the relative abundance of species, rare species were significantly higher (33.33\%) in Sector 9 than that in Sector 7 study site (Fig. 3). In both study sites house crow (Corvus splendens) was most dominant species. The number of bird species which was fairly common and rarely found were significantly different between two ecological sites (Fisher's exact test, $\mathrm{p}<0.05$ ). Lower density of bird species and rare status of the majority of species in Sector 9 indicated that habitat of this study site was not suitable for avifauna.

\section{Breeding records}

A total of 6 species of birds were found to make nest and breed in the gardens of Sector 7. The breeding birds were Corvus splendes, Copsycus saularis, Sturnus contra, Dicrurus macrocercus, Acridotheres tristis and Passer domesticus. The same species was found to breed in Sector 9 also except Dicrurus macrocercus and Acridotheres tristis. A total of 18 nests were recorded in both study sites. It was found that birds made their nest both on indigenous and exotic 
species of plants as well as other substrata. The highest number of nests $(50 \%)$ was investigated on indigenous species of plants followed by nest made on exotic plant species (33.33\%) (Fig. 4). A total of 13 nests were investigated in Sector 7 and only 5 nests in Sector 9 (Fig. 4). The selection of nesting sites by breeding birds on the indigenous trees was significantly higher than that of selection for nesting on other substrata followed by exotic plant trees $\left(\chi^{2}=49.84, \mathrm{p}<0.001, \mathrm{df}=3\right)$. This result suggests that birds prefer nesting sites on indigenous trees rather than exotic trees. Birds in Sector 9 did not make any nest on non-tree objects. From our results we predicted that birds prefer indigenous plants as well as exotic trees to make their nest rather than making nest on non-plant substrata. Therefore, this finding suggests that vegetation is very important factor for the breeding birds to make their nest, get shelter and forage on them.

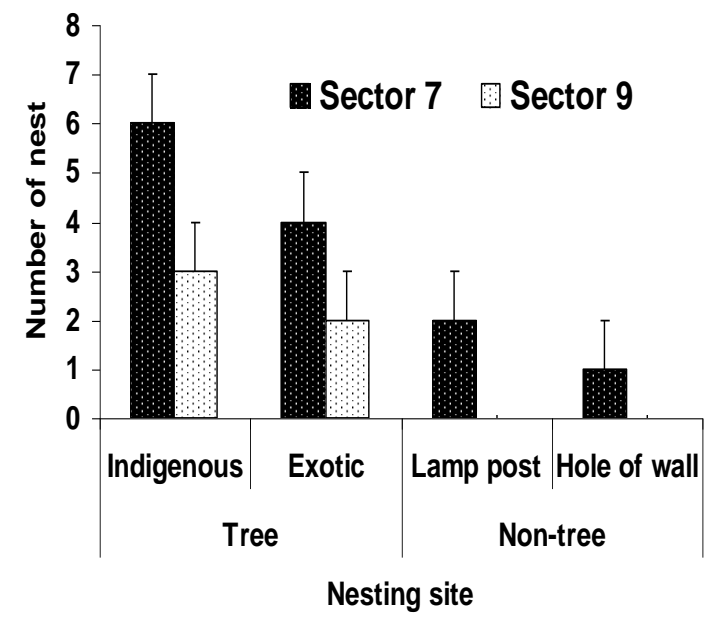

Fig. 4. Nesting sites of the breeding birds recorded in the study sites.

Species diversity and status of each bird species in Sectors 7 and 9 were different as the habitat and vegetation cover were also different. In Sector 7, there were gardens with many natural and planted trees where birds foraged, took shelter and made nest. Thus, physical condition of this site was more natural than in Sector 9. In contrast, Sector 9 had less vegetation cover and had no any park or garden for birds to forage, get shelter and make nest for breeding.

\section{DISCUSSION}

Our study sites are resident area and are still urbanizing. A lot of human interference, constructional activities, noise due to vehicles and peoples are making threat to the species of avifauna. It could be the reason why species diversity was poor in urban area. A good number of bird species are still prevailing on those two study sites. Day by day these areas are going to be a commercial area. Therefore, it is difficult for avifauna to find the nesting locations and sheltering place or foraging habitats in this urban area. Four decades before these areas were covered by thick forest and people avoided to come to this place. In the early eighty's Uttara area was undertaken for urbanization and most of land has been turned into residential and commercial areas and the people cut down the trees and cleared jungles and thickets. Thus, many species of birds either migrated to other places or gradually declined their population as nesting sites were destroyed. To save the urban avifauna, now-a-days reforestation is necessary to create some natural habitat like gardens, parks and lakes besides the human habitation to facilitate the foraging, sheltering and breeding for birds. Plantation of fruit trees within residential area can attract many frugivorous and insectivorous birds to live their. It is well known that birds are friends of human as they destroy lot of harmful insects and mosquitoes from the environment (Jaman et al. 1999). Therefore, a conservation plan should be under taken by the government to save the urban species of birds and their sustainable population. 
Among urban avifauna most common one in the Asia are common crow, house sparrow, myna and egrets. These are found to be more commensal as they always try to live near hman settlements and keep control of insect pests. Among them the house sparrows is originated in the meditaranian area was introduced to all parts of the globe by the European traders as means to control insects and is now established as cosmopolitan species. But sparrows are declining in Europe and some Asian countries. Hence these are placed under red data book in England in 2003. They are also declinig and become rare in indian cities however found in good numbers in villages. It is interesting to note that the sparrows and starling mynas have attained pest status in USA and are not given any legal protection in the USA (Sruti 2008)

The present research work revealed that even though the urban sites are continuously disturbed, still these sites have supported significant number of avifauna. Similarly, earlier studies conducted in Delhi, Pakisthan and Canada (Environment Canada 2009, Anonymous 2006) also revealed good number of avifauna in the areas. It is concluded that in order to attract more and more avifauna to urban areas, we should plant diverse varieties of fruiting trees in our backyards and also offer artifical nesting sites to birds.

\section{ACKNOWLEDGEMENTS}

Authors are grateful to Department of Zoology, University of Dhaka, for the valuable supports during the study period. Authors are also grateful to Mr. Nazrul Haque, keeper natural history department, National Museum, Dhaka for his constructive suggestions in developing ideas on various aspects. We also express our gratitude to Mr. Abdus Satter and some other anonymous researchers who provided us their research papers, ideas and comments on our research work.

\section{REFERENCES}

Akter, S. 1997. The wildlife of Boldha garden, Dhaka, Bangladesh (with notes on ecology, habitat and present status). M. Sc. thesis, Department of Zoology, University of Dhaka, Bangladesh.

Ali, S. 1996. The Book of Indian Birds $\left(11^{\text {th }} \mathrm{Ed}\right)$. Bombay Natural History Society, Bombay, 197 pp.

Ali, S. and S.D. Ripley. 1983a. A Pictorial Guide to the Birds of the Indian Subcontinent. Bombay Natural Society, Bombay, India.

Ali, S. and S.D. Ripley. 1983b. Hand Book of the Birds of India and Pakistan. Compact Ed. Oxford Univ. Press, Delhi, 737 pp.

Anonymous. $2006 . \quad$ Website. WWW.arizonesis.org.sonoran.Fieldguide.html

Anonymous. 2009. Environment Canada Website WWW.ca.gc.ca.

Baker, E.C.S. 1920-30. The Fauna of British India (including Ceylon and Burma) (2nd Ed). Vol. 6. Taylor and Francis, Red lion Court, London.

Banerjee, R.K. 1978. Status and composition of avifauna of the Curzon Hall Campus and Ramna Park, Dhaka. M. Sc. thesis, Department of Zoology, University of Dhaka, Bangladesh.

Das, S.R. 1973. Birds of Sylhet. M. Sc. thesis, Department of Zoology, University of Dhaka, Bangladesh.

Haque, N.M. and M.K. Rahman. 1993. Birds of the Raman and Suhrawardy Parks. Published jointly by the Wildlife Society of Bangladesh (WSB) and Bangladesh Bird Preservation Society (BBPS).

Hossain, M.L., M.F. Jaman and S.U. Sarker. 2004. Diversity of herpeto-mammalian fauna and their conservation issues in Hatiya Island, Bangladesh. Tropical Biodiversity, 8(2):71-78. 
Husain, K.Z. 1969. Field notes on the birds of the Chittagong Hill Tract. J. Asiat. Soc. Pakistan, 13(1):91-101.

Husain, K.Z. 1975. Birds of the Pablakhali Wildlife Sanctuary. Bangladesh J. Zool. 3(2):145-155.

Islam, T. 1969. Birds of Rangpur. M. Sc. thesis, Department of Zoology, University of Dhaka, Bangladesh.

IUCN, 2000. Red Data Book of Threatened Birds of Bangladesh. The World Conservation Union, Dhaka, Bangladesh.

Jaman, M.F. and N. Sahreen. 2004. Ecology and breeding biology of Chestnut-tailed starling, Sturnus malabaricus (Gmellin 1789). Ecoprint, 11(1):27-34.

Jaman, M.F., M.S.Z. Haque and S.U. Sarker. 2004. Ecology, conservation problems and status of avifauna of Noakhali Charbata Coastal area. $J$. Noami, 21(1):1-13.

Jaman, M.F., S.U. Sarker and N.J. Sarker. 1997. Breeding biology of the black drongo, Dicrurus adsimilis albirictus (Hodgson) in Bangladesh. Dhaka Univ. J. Biol. Sci. 6(2):185-194.

Jaman, M.F., S.U. Sarker and N.J. Sarker. 1999. Food habits and feeding behavior of black drongo, Dicrurus macrocercus albirictus (Hodgson). Bangladesh J. Zool. 26(2):57-66.

Khan, M.A.R. 1982. On the major wildlife species of St. Martin Island. Paper presented at the $6 / 7^{\text {th }}$ Annual Bangladesh Science Conference, February, 1982, BARI, Joydebpur, Dhaka. p. 5.

Khan, M.A.R. 1996. Wildlife of Bangladesh (Bangladesher Banyaprani). Vol. 2. Bangla Academy, Dhaka, Bangladesh.
Kotpal, R.L. 1992. A Modern Text Book of Zoology, Vertebrates. Rastogi Publications India.

Lodge, W. 1991. Birds Alternatives Names: A World Checklist. British Library Publications, Sterling Publishing Company Limited, USA.

Sarker, S.U. 1984. Seabirds of the Bay of Bengal off Bangladesh coast and their conservation. Tiger Paper, 11(4):9-13.

Sarker, S.U and N.J. Sarker. 1988. Wildlife of Bangladesh: A Systametic List. The Rico Printers. Nilkhet Babupura, Dhaka. 59 pp.

Sarker, S.U. and N.J. Sarker. 1986. Status and distribution of birds of the Sundarbans. $J$. Noami, 3(1):19-37.

Sarker, S.U., M.F. Jaman, M.L. Hossain and N.J. Sarker. 2001. Wildlife diversity of Moheskhali Island: Their ecology and conservation issues. J. Noami, 18(1):17-31.

Sarker, S.U., M.F. Jaman, N.J. Sarker and M.K. Rahman. 2000b. Diversity of avifauna in Bagkhali range, Cox's Bazar forest division. Bangladesh Environment, pp. 230-238.

Sarker, S.U., M.F. Jaman, N.J. Sarker and M.L. Hossain. 2000a. Status of wildlife of St. Martin Island, Bangladesh. Dhaka Univ. J. Biol. Sci. 9(1):75-85.

Sruti, N. 2008. Ecological studies on house sparrow, Passer domesticus in the bhadravati town, Karnatka state, India. M. Phil. Dissertation, Kuvempu University, Shankarghatta, Karnatka, India.

Wallace, G.J. 1963. An Introduction of Ornithology (2nd ed.). The McMillan Co., New York, USA. 